\title{
OBSERVASI DAUR HIDUP PRODUK PADA BISNIS WARUNG NASI
}

\author{
(Warung Nasi Bpk Hj. Rais dalam Perspektif Pemasaran)
}

\author{
Aan Andriyani \\ Mumuh Mulyana \\ Universitas Terbuka
}

\begin{abstract}
Abstrak
Warung Nasi Bapak Hj. Rais didirikan pada tahun 2005 tepatnya 1 tahun yang lalu oleh Pak Rais yang bermula dari mengikuti usaha atau pekejaan orang tuanya, usaha makanan ini notabennya adalah makanan favorit para karyawan ini, dikarenakan harganya yang sangat ekonomis. Dengan bermodal awal Rp. 1.500.000 Pak Rais dapat menjalankan usahanya hingga sekarang dan dapat mencukupi kebutuhan-kebutuhan keluarganya.

Dari hasil observasi yang telah kami lakukan pada usaha mikro ini, dapat dideskripsikan profil usahanya adalah sebagai berikut: termasuk jenis usaha kuliner, nama usahanya dalah Warung Nasi Bapak Hj. Rais, nama pemiliknya adalah Pak Rais, alamat usahanya berada di Jln. Paralon Raya Kecamatan Cigondewah kaler Kota Bandung, kegiatan usahanya adalah menjual nasi beserta lauk pauk, dengan harga ekonomis sesuai dengan kantong karyawan. Dan waktu perasionalnya adalah pada jam 07.00 - 20.30 WIB.

Bauran pemasaran yang ada pada warung nasi Bapak Hj. Rais antara lain (1) Tempat (Place), yang bertempat di jalan Paralon Raya Kecamatan Cigondewah kaler Kota Bandung . (2) Produk (Product), yaitu nasi dengan berbagai macam lauk maupun sayur. (3) Promosi (Promotion), dengan jenis promosi mulut ke mulut (mouth to mouth). (4) Harga (Price), dengan kisaran harganya mulai dari Rp 8.000 hingga $\mathrm{Rp} 15.000$.

Peluang yang ada di warung nasi Bapak. Hj. Rais adalah menu makanan yang banyak dicari dan sering dijadikan menu utama pilihan bagi para mahasiswa yang lapar dan malas memasak. Sedangkan ancaman warung Nasi Bapak. Hj. Rais adalah banyaknya pesaing yang menjual jenis produk yang sama namun dengan fasilitas yang lebih nyaman. Kekuatan pada warung nasi Bapak. Hj. Rais yaitu kemampuan handal Pak Rais dalam memasak dan menyajikan aneka jenis menu makanan yang dijualnya. Sedangkan kelemahan pada warung nasi Bapak. Hj. Rais yaitu kurangnya fasilitas penunjang yang disediakan seperti TV, wifi, dan sebagainya.

Dalam aspek pemasaran, warung nasi Bapak. Hj. Rais hanya memasang spanduk atau papan nama di tempat usahanya. Sedangkan dalam aspek produksi, warung nasi Bapak. Hj. Rais melakukan produksi berbagai menu makanan setiap harinya sekitar 80 piring. Untuk aspek permodalan Pak Rais memulai usaha warung nasi Bapak. Hj. Rais dengan modal awal Rp. 1.500.000. Dan untuk aspek sumber daya manusia warung nasi Bapak. Hj. Rais tidak melakukan perekrutan pegawai, dengan kata lain, Pak Rais hanya dibantu oleh istrinya saja.

Strategi bersaing yang diterapkan warung Nasi Bapak Hj. Rais adalah Pertama, warung nasi Bapak Hj. Rais selalu berfokus pada produk utamanya saja, yaitu nasi campur telor dengan tujuan meningkatkan pelayanan kepada pelanggan untuk mencapai kepuasan pelanggan. Kedua, warung nasi Bapak. Hj. Rais menekan harga jual produk yang dipasarkan dengan tidak
\end{abstract}


mengurangi kualitas bahan-bahan yang dibeli untuk menjual menu makanannya, hal tersebut dapat dilakukan karena Pak Rais memiliki hubungan yang baik dengan para suppliernya.

\section{BAB I \\ PENDAHULUAN}

\section{A. Latar Belakang Observasi}

Dalam ilmu ekonomi, Bisnis adalah suatu organisasi yang menjual barang atau jasa kepada konsumen atau bisnis lainnya, untuk mendapatkan laba. Secara historis kata bisnis dari bahasa Inggris business, dari kata dasar busy yang berarti "sibuk" dalam konteks individu, komunitas, ataupun masyarakat. Dalam artian, sibuk mengerjakan aktivitas dan pekerjaan yang mendatangkan keuntungan.

Kasmir dan Jakfar (2012:7) "bisnis adalah usaha yang dijalankan yang tujuan utamanya adalah keuntungan". Dengan demikian Bisnis memiliki tujuan utama yaitu mendapatkan keuntungan dengan cara mengolah barang mentah dengan semua sumber daya yang dimiliki oleh suatu perusahaan untuk di perjual belikan supaya mendapatkan keuntungan.

Para pelaku dunia bisnis atau usaha pasti akan mempertimbangkan bagaimana cara untuk bisa menarik perhatian konsumennya supaya bisnis atau usahanya berjalan dengan lancar sehingga bisa mencapai tujuan utamanya yaitu mendapatkan keuntungan. Para pelaku usaha yang tidak memiliki daya tarik untuk mendapatkan pelanggan pasti tidak akan bisa bertahan di dunia usaha.

Salah satu strategi usaha makanan yang bisa menarik konsumen sehingga menjadikan suatu bisnis makanan tersebut menjadi berjalan dan berkembang adalah dengan menekan harga jual tanpa mengurangi kualitas produk yang dijual sehingga dapat menjadikan warung tersebut mendapatkan konsumen yang banyak dan loyal.

Persaingan dalam memperebutkan konsumen di jalan Paralon Raya Cigondewah Kaler Kota Bandung sangatlah berjalan ketat. Sehingga memaksa para pemilik usaha terutama kuliner untuk melakukan berbagai macam strategi untuk menarik minat konsumen, ada yang memilih menambah daftar menu makanan yang dijual, mengurangi harga, menambah jumlah nasi dalam satu porsi, dan ada yang memberikan minuman gratis bagi konsumen yang membeli makanan warung tersebut. 
Laporan observasi ini membahas tentang strategi penjualan makanan di jalan Paralon Raya Cigondewah Kaler Kota Bandung yang dilakukan oleh warung Nasi Bapak $\mathrm{Hj}$. Rais yang dimiliki dan dikelola oleh Pak Rais dan keluarga. Didalam laporan observasi ini akan dibahas berbagai aspek yang menyokong atau membangun warung nasi Bapak. Hj. Rais dalam berbagai kegiatan ekonominya, baik dari awal berdirinya, bagaimana strategi pemasarannya, masalah suberdaya manusia, permodalan, operasionalnya, dan lain sebagainya.

\section{B. Rumusan Masalah}

Dari latar belakang observasi yang telah dipaparkan diatas maka rumusan masalahnya sebagai berikut:

1. Produk apa yang dijual

2. Berapa Harga jual produk

3. Bentuk Promosi apa yang dilakukan

4. Bentuk pendistribusian yang dilakukan.

5. Berjualan sejak tahun berapa

6. Jumlah karyawan yang terlibat dalam operasional bisnis

7. Omset per harinya berapa

8. Siapa saja Konsumen yang membeli produknya

9. Buka jam berapa dan tutup jam berapa?

10. Usaha ini milik siapa?

\section{Manfaat Observasi}

Dengan demikian observasi ini diharapkan bisa memberi manfaat bagi pihak-pihak yang berkepentingan didalamnya, antara lain:

1. Bagi kelompok observasi, kami berharap observasi ini bisa dijadikan motivasi dan pertimbangan untuk berwirausaha atau menciptakan lapangan pekerjaan.

2. Bagi para pedagang, observasi ini diharapkan menjadi motivasi untuk mengembangkan usahanya sebagai perilaku wirausaha. 
3. Bagi pembaca, observasi ini diharapkan bisa menjadi pedoman dalam memperoleh gagasan untuk menciptakan suatu bisnis dan menjalankannya dengan strategi yang baik.

4. Bagi pihak warung Nasi Bapak $\mathrm{Hj}$. Rais, observasi ini diharapkan menjadi bahan pertimbangan dalam membuat keputusan dan kebijakan dalam kegiatan operasional warung Nasi Bapak Hj. Rais.

\section{BAB II \\ KAJIAN TEORI}

\section{A. Tinjauan Teori}

1. Pasar dan Pemasaran

Pasar adalah hasil dan kegiatan atau proses yang dinamakan pemasaran. Jadi dengan kata lain pemasaran adalah kegiatan manusia dalam hubungannya dengan pasar. Dalam arti sempit pemasaran sering diartikan sebagai kegiatan menyalurkan atau mendistribusikan barang/jasa kepada konsumen. Pengertian pemasaran dalam arti luas salah satunya adalah seperti apa yang dikemukakan oleh Philip Kotler sebagai berikut: Pemasaran adalah proses sosial dan manajerial dimana individu dan kelompok mendapatkan kebutuhan dan keinginan mereka dengan menciptakan, penawarkan produk yang bernilai satu sama lain. (Anonim. 2010)

Manajemen pemasaran berasal dan dua kata yaitu manajemen dan pemasaran. Pengertian manajemen pemasaran tersebut merupakan pengertian gabungan dan dua pengertian kata tersebut. lstilah manajemen secara sederhana sering diartikan sebagai pengelolaan, pengaturan, pembinaan, penataaan, dan istilah-istilah lainnya. Pengertian manajemen secara luas (definisi) sangat banyak sekali, tetapi dan definisi-definisi yang ada tersebut secara garis besar memiliki unsur-unsur yang hampir sama. Manajemen secara secara umum diartikan sebagai suatu proses yang di dalamnya secara garis besar tercakup fungsi-fungsi perencanaan, pengorganisasian, penggerakkan, pengawasan, dan pengevaluasiaan. Atau secara sederhana fungsi-fungsi tersebut dikatagorikan ke dalam perencanaan, pelaksanaan, dan pengawasan. (Anonim 2011)

Salah satu pengertian manajemen pemasaran adalah seperti yang dikemukakan oleh Philip Kotler yang mengutip definisi yang digunakan oleh Persatuan Pemasaran Amerika sebagai berikut: Manajemen Pemasaran adalah proses perencanaan dan pelaksanaan dan perwujudan, 
pemberian harga, promosi, dan distribusi dan barang-barang, jasa, dan gagasan untuk menciptakan pertukaran dengan kelompok sasaran yang memenuhi tujuan pelanggan dan organisasi. (Anonim 2011)

2. Saluran Pemasaran

Walter (1977) dalam Basuswastha (1981) mengatakan bahwa saluranpemasaran adalah sekelompok pedagang dan agen yang mengkombinasikan antarapemindahan fisik dan nama dari suatu produk untuk menciptakan kegunaan bagipasar tertentu.Menurut Soetrisno (2003), saluran pemasaran dapat berbentuk sederhana dandapat pula rumit sekali. Hal tersebut tergantung pada macam komoditi lembagapemasaran dan sistem pasar. Sistem pasar yang monopoli memiliki saluranpemasaran yang relatif sederhana dibanding sistem pasar yang lain. Barang yanglebih cepat ke tangan konsumen biasanya mempunyai saluran pemasaran yang relative sederhana. (anonim 2011)

Beberapa saluran pemasaran barang konsumsi dengan panjang yang berbeda :

Saluran nol tingkat (saluran pemasaran langsung), terdiri dari suatu perusahaan manufaktur yang menjual langsung ke pelanggan akhir.

Saluran satu tingkat, berisi satu perantara penjualan seperti pengecer.

Saluran dua tingkat, berisi tiga perantara, misalnya dalam industri pengemasan daging, pedagang besar menjual ke pemborong yang akan menjualnya ke beberapa pengecer kecil

\section{Margin Pemasaran}

Margin pemasaran atau margin tataniaga menunjukkan selisih harga dari dua tingkat rantai pemasaran. Margin tataniaga adalah perubahan antara harga petani dan harga eceran (retail. Margin tataniaga hanya merepresentasikan perbedaan harga yang dibayarkan konsumen dengan harga yang diterima petani, tetapi tidak menunjukkan jumlah quantitas produk yang dipasarkan. Margin tataniaga merupakan penjumlahan antara biaya tataniaga dan margin keuntungan.

Nilai margin pemasaran adalah perbedaan harga di kedua tingkat sistim pemasaran dikalikan dengan quantitas produk yang dipasarkan. Cara perhitungan ini sama dengan konsep nilai tambah (value added). Pengertian ekonomi nilai margin pemasaran adalah harga dari sekumpulan jasa pemasaran/tataniaga yang merupakan hasil dari interaksi antara permintaan dan 
penawaran produk-produk tersebut. Oleh karena itu nilai margin pemasaran dibedakan menjadi dua yaitu marketing costs dan marketing charges (Dahl, 1977).

Biaya pemasaran terkait dengan tingkat pengembalian dari faktor produksi, sementara marketing charges berkaitan dengan berapa yang diterima oleh pengolah, pengumpul dan lembaga tataniaga. Margin tataniaga terdiri dari tiga jenis yaitu absolut, persentase dan kombinasi. Margin pemasaran absolut dan persentase dapat menurun, konstan dan meningkat dengan bertambahnya quantitas yang dipasarkan. Hubungan antara elastisitas permintaan di tingkat rantai tataniaga yang berbeda memberikan beberapa kegunaan analisis. Hubungan bergantung pada perilaku dari margin pemasaran. (anonim 2011)

\section{Efisiensi Pemasaran}

Yang dimaksud dengan efisiensi pemasaran adalah seberapa besar pengorbanan yang harus dikeluarkan dalam kegiatan pemasaran menunjang hasil yang bisa didapatkan dari kegiatan pemasaran tersebut. Efisiensi pemasaran dapat dicari dengan menghitung rasio "keluaranmasukan" dalam kegiatan pemasaran yang dilakukan. Semakin tinggi nilai rasio keluaranmasukan, maka pemasaran yang dilakukan semakin efisien. Umumnya efisiensi dapat dicapai dengan salah satu di antara empat cara berikut :

Keluaran tetap konstan, masukan mengecil

Keluaran meningkat, masukan konstan

Keluaran meningkat dalam kadar yang lebih tinggi dari peningkatan masukan

Keluaran menurun dalam kadar yang lebih rendah dari penurunan masukan

\section{BAB III \\ METODE OSERVASI}

\subsection{Lokasi Observasi}

Kegiatan observasi ini dilakukan di Warung Nasi Bapak $\mathrm{Hj}$. Rais. Objek observasi ini adalah berbagai macam kegiatan perekonomian yang ada di Warung Nasi Bapak Hj. Rais yang bertempat di Jln. Paralon Raya Kecamatan Cigondewah Kaler Kota Bandung. 


\subsection{Jenis dan Pendekatan Observasi}

Untuk memperoleh jawaban dari permasalahan yang diambil dan sesuai dengan tujuan observasi ini, maka jenis observasi yang sesuai adalah observasi deskriptif dengan menggunakan analisis data kualitatif dan kuantitatif, karena objek dari observasi ini merupakan suatu fenomena atau kenyataan sosial. Hal ini sesuai dengan yang dikatakan oleh Sanapiah Faisal (1996:20) bahwa "observasi deskriptif atau observasi taksonomik atau observasi eksplorasi dimaksudkan untuk eksplorasi dan klarifikasi mengenai suatu fenomena atau kenyataan sosial, dengan jalan mendiskripsikan sejumlah variabel yang berkenaan dengan masalah dan unit yang diteliti tanpa mempersoalkan jalinan hubungan antar variabel yang ada". Karena itu pada observasi deskriptif tidak dilakukan pengujian hipotesis untuk membangun dan mengembangkan perbendaharaan teori.

Sedangkan menurut NDraha (1985:105) berpendapat bahwa "observasi deskriptif merupakan suatu observasi yang bertujuan untuk menemukan pengetahuan tentang seluasluasnya objek riset pada suaty masa atau saat tertentu".

\subsection{Jenis Data}

Semua data yang diperoleh melalui sumber dokumentasi merupakan informasi yang dapat dujadikan narasumber data, karena dianggap menguasai bidang permasalahan dan berhubungan erat dengan pelaksanaan seluruh kegiatan untuk mempermudah penyelesaian masalah dalam observasi. Jenis sumber data yang digunakan dapat dibedakan menjadi dua bagian yaitu:

\subsubsection{Data Primer}

Yaitu data yang diperoleh ssecara langsung pada saat kita melakukan observasi, sumber data yang diperoleh secara langsung dari orang-orang atau responden yang secara sengaja dipilih untuk memperoleh data-data atau informasi yang ada relefansinya dengan permasalahan observasi. Adapun yang menjadi data primer dalam observasi ini adalah:

\subsubsection{Penelitian Sendiri}

Yaitu dalam memperoleh data, observasi sebagai instrument mengamati serta mencatat fenomena objek yang terjadi untuk diobservasi dan yang berkaitan dengan permasalahan observasi. Pedoman wawancara dengan narasumber untuk mendapatkan datayang berkaitan dengan focus observasi. Catatan lapangan yang berupa catatan-catatan yang dipergunakan untuk mencatat informasi terutama selama observasi. 


\subsubsection{Informan}

Menurut Maleong (2000:90) "Informan merupakan orang dalam yang diginakan dalam untuk memberikan keterangan dan informasi tentang situasi dan kondisi latar belakang observasi".

Adapun narasumber atau infoman yang dipilih untuk dijadikan narasumber primer adalah Bapak Hj. Rais (sebagai pemilih Warung Nasi Bapak Hj. Rais) dan para karyawannyanya.

\subsubsection{Data Sekunder}

Yaitu yang dikutip dari sumber-sumber tertentu yang digunakan sebagai pendukung data primer, sumber data sekunder ini merupakan sumber data yang melengkapi serta memperkaya sumber data primer atau sember data sekunder ini diperoleh dari data pendukung. Data sekunder yang merupakan sumber data yang akan melengkapi sumber data primer, yaitu para pengusaha atau tetangga yang ada disamping Warung Nasi Bapak Hj. Rais.

\subsection{Metode Pengumpulan Data}

Teknik pengumpulan data yang digunakan dalam observasi ini adalah:

\subsubsection{Wawancara}

Wawancara meupakan teknik pengumpulan data yang dilakukan dengan cara Tanya jawab antara kelompok observasi dengan informan yang telah dijadikan sumber data. Wawancara dilakukan dengan maksud untuk memperoleh informasi secara langsung untuk dijadikan data yang tidak diperlukan dari sumber data yang lain.

Wawancara dilakukan dengan cara Tanya jawab secara langsung, dimana kelompok observasi menggunakan teknik mengikat dan disesuaikan dengan dengan keadaan saat itu guna mendapatkan data yang sebanyak mungkin dari informan sebagai sumber data dengan cara mencatat atau merekam hasil wawancara tersebut.

Penentuan informan didasarkan pada prediksi kemampuan informan dalam memberikan data-data yang diperlukan sesuai dengan rumusan masalah. Wawancara dalam observasi ini akan dilakukan dengan Bapak Hj. Rais yang tidak lain adalah pemilik Warung Nasi Bapak. Hj. Rais. Informan tersebut ditentukan sesuai dengan data yang diperlukan.

\subsubsection{Observasi}


Adalah suatu teknik pengumpuan data yang dilakukan melalui pengamatan secara langsung dari dekat terhadap fenomena objek yang terjadi atau diteliti, sehingga memungkinkan untuk memperoleh gambaran dari fenomena yang sulit diperoleh dari orang-orang yang dijadikan sumber data. Teknik dilakukan karena untuk mencari dan mendapatkan "sesuatu" diluar atau tidak mungkin diperoleh dari sumber data langsung, sehingga dapat diharapkan nilai data yang diterima melalui pengamatan langsung akan memberikan kekuatan pandangan tentang nilai atau validalitas data tersebut, sebagai pembanding dari sumber data buku yang ada. Dan dalam observasi ini teknik observasi yang digunakan adalah observasi nonpartisipan. Teknik ini dilakukan dengan jalan kelompok observasi langsung ke objek observasi untuk mendapatkan fakta melaui pendekatan pada tiap-tiap sember data guna memperoleh gambaran tentang kebiasaan meraka, prosedur pelayanan, dan tanggapan dari masyarakat.

\subsubsection{Dokumentasi}

Dokumentasi merupakan teknik pengumpulan data yang dilakukan dengan cara meneliti dokumen-dokumen yang relevan dengan permasalahan observasi. Dengan teknik ini akan terkumpul data yang diperoleh dari narasumber tetapi tedapat pada berbagai sumber tertulis, seperti dokumen-dokumen yang dikeluarkan oleh pengurus kantin, laporan-laporan dan arsiparsip lainnya.

Dokumentasi diperlukan untuk memperoleh data-data yang relevan dengan permasalahan observasi yang tidak mungkin diperoleh dengan observasi dan interview. Dokumentasi dilakukan dengan cara memilih dokumen-dokumen yang ada dan diambil data yang relevan dengan permasalahan observasi.

\subsection{Metode Analisis Data}

Analisis data menurut Sanapiah Faisal (1999:255-258) terdiri dari tiga alur kegiatan yaitu:

\subsubsection{Reduksi Data}

Yang merupakan proses merangkum, mengikhtisarkan atau menyeleksi data dari catatan lapangan yang kemudian dimasukkan dalam kategori tema yang mana, fokus atau permasalahan yang mana sesuai dengan focus observasi.

\subsubsection{Penyajian Data}


Merupakan proses penyajian data kedalam sejumlah matrik yang sesuai yang berfungsi untuk memetakan data yang telah direduksi, juga untuk memudahkan mengkontruksi didalam rangka menuturkan, menyimpulkan dan menginterprestasikan data.

\subsubsection{Menarik Kesimpulan}

Yaitu membuat suatu kesimpulan sementara yang dapat dijadikan sebagai suatu pembekalan dalam melaksakan observasi untuk memberikan penafsiran dari data yang diperoleh terutama data yang berhubungan dengan fokus observasi. Penarikan kesimpulan atau vertifikasi dilakukan dengan longgar, tetap terbuka, tetapi semakin lama lebih semakin rinci berdasarkan kumpulan-kumpulan data yang diperoleh dilapangan dan mengakar dengan kokoh. Data yang diperoleh dilapangan disajikan sedemikian rupa, kemudian dianalisa terhadap data tersebut untuk memperoleh hasil yang sebenarnya.

\section{BAB IV \\ PEMBAHASAN LAPORAN OBSERVASI \\ WARUNG NASI BAPAK HJ. RAIS}

\section{A. Latar Belakang Usaha}

Bermula dari mengikuti jejak orang tuanya, Pak Rais akhirnya mendirikan usaha kecilkecilan di bidang makanan siap saji, yaitu warung nasi Bapak Hj. Rais. Usaha yang notabennya adalah menu makanan untuk para karyawan ini, dikarenakan harganya yang sangat ekonomis. Warung Nasi Bapak Hj. Rais ini dirikan pada tahun 2005, tepatnya sekitar 14 tahun yang lalu dengan modal awal sekitar 1.500.000 rupiah. Modal awal ini Pak Rais peroleh dari hasil uang simpanannya atau tabungannya. Pak Rais dapat menjalankan usahanya hingga sekarang. Kini, dari hasil penjualannya ini beliau mampu meraup omset kurang lebih sebesar Rp 800.000,perharinya. Sehingga keuntungan yang dapat beliau peroleh perharinya yaitu sebesar Rp 400.000,- dengan asumsi 80 piring habis terjual. Jika diakumulasikan dalam setahun bisa diperoleh omset bersih kurang lebih sebesar 120.000.000 rupiah setelah dikurangi beban penyusutan peralatannya. 


\section{B. Profil Usaha}

Dari hasil observasi yang telah kami lakukan pada usaha mikro ini, dapat dideskripsikan profil usahanya yang dituliskan sebagai beikut.

$\begin{array}{ll}\text { Jenis usaha } & \text { : Kuliner } \\ \text { Nama usaha } & \text { : Warung Nasi Hj. Rais } \\ \text { Nama pemilik } & : \text { Pak Rais } \\ \text { Alamat usaha } & \text { : Jl. Paralon Raya Kecamatan Cigondewah Kaler Bandung } \\ \text { Kegiatan } & \text { : Menjual nasi beserta lauk pauk, dengan harga ekonomis } \\ & \text { sesuai dengan kantong Karyawan . } \\ \text { Waktu operasi } & : 07.00-20.30 \text { WIB }\end{array}$

\section{Target Penjualan}

Dalam laporan observasi ini, target penjualan warung nasi Bapak. Hj. Rais terhadap pasar adalah kalangan para karyawan yang berada di Wilayah Jalan. Pralon Raya Kecamatan Cigondewah Kaler Kota Bandung, dan terutama sekitar Daerah Cigondewah dimana Warung Nasi Bapak Hj. Rais berada.

\section{Jangkauan Terhadap Konsumen}

Dalam laporan observasi ini, kami menemukan bahwa yang dilakukan oleh warung Nasi Bapak Hj. Rais untuk menjangkau konsumen adalah dengan cara pendekatan secara personal pribadi kepada pelanggannya, jadi pemilik warung nasi Bapak Hj.Rais akan berusaha untuk menjadi akrab dan dekat kepada konsumennya yang tidak lagi adalah para karyawan. Hal ini dilakukan dengan tujuan akhir yaitu diharapkan para konsumen tadi melakukan promosi dari mulut ke mulut tentang keberadaan warung nasi Bapak $\mathrm{Hj}$. Rais yang mempunyai menu kelas karyawan.

\section{E. Bauran Pemasaran pada Usaha Warung Nasi Bapak Hj. Rais}

Dari hasil observasi ini, didapatkan data mengenai bauran pemasaran yang ada pada warung Nasi Bapak Hj.Rais. Adapun rinciannya sebagai berikut.

Tempat (Place) 
Lokasi yang diambil oleh Pak Rais dalam menjalankan usahanya yaitu di jalan Paralon Raya Kecamatan Cigondewah Kaler Kota Bandung. Pak Rais membuka warung nasi Bpk.Hj. Rais di samping Pabrik Kue Merek Kartikasari yang sangat terkenal di Kota Bandung, selain itu banyaknya kos-kosan karyawan juga di daerah sana. Lokasi ini terletak di pinggir jalan, dan tergolong strategis, karena pasalnya dekat dengan pabrik-pabrik dan tidak jauh dengan pasar Cigondewah.

Produk (Product)

Pada umumnya, produk yang ditawarkan oleh Pak Rais dalam usahanya yaitu nasi dengan berbagai macam lauk maupun sayur, di mana menu ini dikemas dengan varbeliausi rasa yang berbeda sesuai dengan jenisnya. Selain menjual nasi dengan lauk yang beraneka jenis dan rasa, beliau juga menjual aneka minuman jus yang tentunya memiliki variasi jenis yang berbeda juga. Adapun produk makanan dan minuman yang dijajankan oleh Pak Rais yaitu:

\begin{tabular}{|l|l|}
\hline \multicolumn{1}{|c|}{ MAKANAN } & \multicolumn{1}{c|}{ HARGA } \\
\hline Nasi pecel & Rp. 12.000 \\
\hline Nasi penyet tempe & Rp. 13.000 \\
\hline Nasi campur + telor & Rp. 10.000 \\
\hline Nasi tahu telor & Rp. 8.000 \\
\hline Nasi martabak & Rp. 14.000 \\
\hline Nasi kare ayam & Rp. 15.000 \\
\hline Nasi goreng jawa & Rp. 13.000 \\
\hline
\end{tabular}

\begin{tabular}{|l|l|}
\hline \multicolumn{1}{|c|}{ MINUMAN } & \multicolumn{1}{c|}{ HARGA } \\
\hline Es teh & Rp. 2.500 \\
\hline Es jeruk & Rp. 3.000 \\
\hline Teh hangat & Rp. 2.000 \\
\hline Jeruk hangat & Rp. 3.000 \\
\hline Kopi hitam & Rp. 3.000 \\
\hline Kopi susu & Rp. 4.500 \\
\hline Aneka jus & Rp. 5.000 \\
\hline
\end{tabular}

Promosi (Promotion) 
Dalam memasarkan dagangannya, Pak Rais hanya memasang spanduk atau papan nama di tempat usaha. Sedangkan strategi promosi paling efektif yang diterapkan oleh Pak Rais adalah dengan jenis promosi mulut ke mulut (mouth to mouth). Promosi jenis ini baru akan terjadi jika konsumen puas dengan cita rasa menu yang telah dijual.

Harga (Price)

Harga yang ditawarkan oleh Pak Rais ini tergolong relative murah. Kisaran harganya mulai dari Rp 8.000 hingga Rp 15.000. Harga ini tergantung dari jenis menu mana yang akan dipesan pelanggan.

\section{F. Analisis Lingkungan Eksternal dan Internal pada Usaha Warung Nasi Bapak Hj. Rais}

Selain mendapatkan data mengenai bauran pemasaran yang ada pada usaha warung Nasi Bapak Hj. Rais ini, kami juga mendapatkan data lain, yang kemudian bisa kami jabarkan dalam analisis lingkungan eksternal dan internal dengan menggunakan analisis SWOT di bawah ini.

1. Identifikasi Peluang dan Ancaman Eksternal (Opportunity - Threat)

Peluang (Opportunity)

Menu makanan di warung nasi Bapak Hj. Rais banyak dicari dan sering dijadikan menu utama pilihan bagi para karyawan yang lapar dan malas memasak. Selain itu, menu makanan yang dijual Pak Rais kepada para pelanggannya ini memiliki kualitas dan cita rasa yang baik dibandingkan dengan para pesaingnya, walaupun pesaing memiliki kelebihan dalam hal inovasi. Karena peluang-peluang inilah yang membuat Pak Rais memilih usaha ini sebagai ladang penghasilan hidupnya.

Ancaman (Threat)

Ancaman eksternal yang dihadapi oleh Pak Rais yaitu banyaknya pesaing yang menjual jenis produk yang sama namun dengan fasilitas yang lebih nyaman, dan inovasi-inovasi yang lebih unggul. Selain itu, banyak pesaing lain yang dalam menjual dagangannya masih dengan cara berkeliling, sehingga mereka lebih mudah untuk menjangkau pelanggan. Ancaman-ancaman ini bisa membuat pelanggan lebih memilih membeli menu-menu makanan di pesaingnya ketimbang di Pak Rais. Sehingga apabila ini dibiarkan, maka tidak menutup kemungkinan usaha Pak Rais akan mengalami penurunan omset penjualannya.

2. Kesadaran akan Kekuatan dan Kelemahan Internal (Strength - Weakness) 


\section{Kekuatan (Strength)}

Kekuatan internal yang ada pada usaha Pak Rais ini yaitu memiliki kemampuan handal dalam memasak dan menyajikan aneka jenis menu makanan yang dijualnya. Pak Rais juga mampu mempertahankan cita rasa menu makanannya yang enak dari awal berdirinya hingga sekarang. Pak Rais mempunyai sifat yang ramah kepada semua orang, yang mana ini bisa menjadi bekal tersendiri bagi Pak Rais dalam memberikan pelayanan yang baik kepada para pelanggan, sehingga dapat meningkatkan loyalitas. Dengan kekuatan-kekuatan internal yang dimilikinya inilah, yang membuat Pak Rais mampu mengambil peluang yang ada dan mampu bersaing dengan penjual makanan yang lain.

\section{Kelemahan (Weakness)}

Kelemahan internal yang ada pada usaha Pak Rais ini yaitu kurangnya fasilitas penunjang yang disediakan seperti TV, wifi, dan sebagainya. Tempat makan yang disediakan pun juga kurang bersih. Sehingga pelanggan merasa kurang nyaman ketika makan di tempat. Selain itu, pemilik juga kurang melakukan inovasi-inovasi produk baru yang lebih diminati pelanggan.

\section{G. Strategi pada Usaha Warung Nasi Bapak. Hj. Rais Ditinjau dari Berbagai Aspek}

Dalam menjalankan usaha warung nasi Bapak. $\mathrm{Hj}$. Rais menerapkan beberapa strategi yang dapat ditinjau berdasarkan beberapa aspek, dbeliauntaranya yaitu:

\section{Aspek Pemasaran}

Dalam memasarkan dagangannya, Pak Rais hanya memasang spanduk atau papan nama di tempat usaha. Selain itu, beliau membuat lampu dengan penerangan yang cukup saat berjualan sehingga dapat terlihat dari kejauhan. Sedangkan strategi promosi paling efektif yang diterapkan oleh Pak Rais adalah dengan jenis promosi mulut ke mulut (mouth to mouth) dari para pelanggan yang telah membeli.

2. Aspek Produksi

Dalam hal ini, Pak Rais melakukan produksi berbagai menu makanan setiap harinya sekitar 80 piring. Adapun bahan dasar yang diperlukan dalam pembuatan menu makanannya yaitu:

Beras

Minyak goreng

Mentega 


$\begin{array}{lll}\text { Bawang daun } & \text { Garang } & \text { Lada halus } \\ \text { Bawang putih } & \text { Telor ayam } & \text { Cabe merah } \\ \text { Bawang merah } & \text { Mentimun } & \text { Kecap } \\ \text { Penyedap masakan } & \text { Kacang panjang } & \text { Tahu Tempe } \\ \text { Tomat } & \text { Mie } & \text { Sawi } \\ \text { Bayam } & \text { Kangkung } & \text { Wortel } \\ \text { Gubis } & \text { Ketumbar } & \text { DLL }\end{array}$

Berikut proses singkat pembuatan salah satu menu makanan warung nasi Bapak. Hj. Rais yaitu nasi campur telor, yaitu:

- Masak beras beserta air sampai meletup- letup, sambil diaduk-aduk supaya bawahnya tidak gosong, sampai nasi matang.

- Goreng tahu dan tempe yang sudah dipotong kotak-kotak kecil, sisihkan, kemudian goreng telur ayam.

- Tumis bawang merah dan bawang putih, sisihkan sebagian untuk ditaburkan, masukkan tahu, telur, bumbu masakan, dan aduk-aduk kemudian cek rasa, jika sudah matikan kompor.

- Masukkan nasi putih pulen ke dalam cetakan, padatkan lalu tuangkan pada piring saji. Atur tata letaknya di bagian tengah piring.

- Kemudian letakan lauk pauk seperti telur, tempe, mie bihun goreng, dan potongan tahu goreng pada bagian pinggiran nasi. Tambahkan juga dengan secukupnya sambal dan lalapan jika memang suka.

- Taburi bagian atas nasi dengan bawang goreng agar lebih beraroma sedap dan lengkapi dengan tambahan kerupuk renyah atau rempeyek. Hidangkan nasi campur komplit.

- Sajikan selagi hangat.

\section{Aspek Permodalan}

Modal awal yang digunakan Pak Rais untuk memulai usaha warung nasi Bapak. Hj. Rais nya yaitu sebesar Rp. 1.500.000, yang diperoleh dari hasil simpanan atau tabungannya. Modal awal ini beliau gunakan untuk membeli segala macam peralatan seperti membeli gerobak, piring, sendok, garpu, kompor, dan peralatan lainnya yang sekiranya dapat digunakan untuk menunjang 
usaha bisnisnya. Modal sehari-hari yang digunakan untuk membuat atau memproduksi menu makanannya yaitu sebesar Rp. 400.000 yang digunakan untuk membeli beras, minyak goreng, serta bahan-bahan lainnya. Namun, modal tersebut mungkin saja lebih kecil apabila terdapat bahan-bahan atau bumbu-bumbu yang masih ada atau masih tersisa untuk digunakan pada hari berikutnya. Lalu untuk mengitung omset per hari, dbeliausumsikan harga menu makanannya dikali dengan jumlah unit, di sini dbeliausumsikan 80 piring habis terjual.

Berikut informasi singkat keuangan penjualan warung Nasi Bapak Hj. Rais:

\begin{tabular}{|l|l|l|}
\hline \multicolumn{3}{|c|}{$\begin{array}{c}\text { INFORMASI KEUANGAN PENJUALAN } \\
\text { WARUNG NASI BAPAK. HJ. RAIS }\end{array}$} \\
\hline Modal per hari & Rp. 400.000 & \\
\hline $\begin{array}{l}\text { Omset per hari (80 piring @ } \\
\text { Rp. 10.000 }\end{array}$ & Rp. 800.000 & \\
\hline Laba bersih perhari & & Rp. 400.000 \\
\hline $\begin{array}{l}\text { Laba kotor per bulan (Rp. } \\
\text { 400.000 @ 30 hari) }\end{array}$ & Rp. 12.000.000 & \\
\hline $\begin{array}{l}\text { Beban penyusutan peralatan } \\
\text { per bulan }\end{array}$ & Rp. 2.000 .000 & \\
\hline Laba bersih per bulan & & Rp. 10.000 .000 \\
\hline $\begin{array}{l}\text { Laba bersih per tahun (Rp. } \\
\text { 10.000.000 @ 12 bulan) }\end{array}$ & & Rp. 120.000 .000 \\
\hline
\end{tabular}

4. Aspek Sumber Daya Manusia

Dalam menjalankan usaha warung Nasi Bapak Hj. Rais, Pak Rais tidak melakukan perekrutan pegawai. Dengan kata lain, beliau hanya dibantu oleh istrinya saja. Namun, pada harihari besar, misalnya hari lebaran, pemilik kerap kali meminta bantuan dari saudaranya untuk membantunya berjualan. Hal ini dikarenakan, pada hari-hari besar seperti itu, pelanggan terus meningkat.

\section{H. Kebijakan Strategi Bersaing pada Usaha warung nasi Bapak. Hj. Rais}


Dari hasil wawancara yang telah kami lakukan, kami dapat menganalisis bahwa strategi bersaing yang diterapkan oleh pemilik usaha adalah sebagai berikut:

1. Fokus

Dalam menjalankan usahanya, Pak Rais selalu berfokus pada produk utamanya saja, yaitu nasi campur telor. Dengan melakukan strategi ini maka pemilik dapat berfokus untuk meningkatkan pelayanan kepada pelanggan untuk mencapai kepuasan pelanggan. Cara yang beliau lakukan yaitu dengan memperhatikan kualitas nasi campur telor yang dijualnya serta dengan meningkatkan cita rasa yang tenggi agar pelanggan tidak merasa kecewa setelah membelinya.

2. Kepemimpinan (Cost Leadership)

Pak Rais yang tidak lain adalah pemilik usaha warung nasi Bapak.Hj. Rais menerapkan strategi kepemimpinan, di mana beliau menjual produknya dengan harga yang relatif terjangkau dibandingkan dengan penjual nasi makanan yang sejenis lainnya. Hal ini dapat dicapai dengan cara menekan harga jual yang dipasarkan dengan tidak mengurangi kualitas bahan-bahan yang dibeli untuk menjual menu makanannya. Hal tersebut dapat dilakukan karena pemilik memiliki hubungan yang baik dengan para supplier atau telah berlangganan dengan suatu penjual bahanbahan dalam memproduksi makanan sehingga pemilik diberikan harga yang murah.

\section{BAB III \\ PENUTUP}

\section{A. Kesimpulan}

Warung Nasi Bapak Hj. Rais didirikan pada tahun 2005 tepatnya 1 tahun yang lalu oleh Pak Rais yang bermula dari mengikuti usaha atau pekejaan orang tuanya, usaha makanan ini notabennya adalah makanan favorit para karyawan ini, dikarenakan harganya yang sangat ekonomis. Dengan bermodal awal Rp. 1.500.000 Pak Rais dapat menjalankan usahanya hingga sekarang dan dapat mencukupi kebutuhan-kebutuhan keluarganya.

Dari hasil observasi yang telah kami lakukan pada usaha mikro ini, dapat dideskripsikan profil usahanya adalah sebagai berikut: termasuk jenis usaha kuliner, nama usahanya dalah Warung Nasi Bapak Hj. Rais, nama pemiliknya adalah Pak Rais, alamat usahanya berada di Jln. 
Paralon Raya Kecamatan Cigondewah kaler Kota Bandung, kegiatan usahanya adalah menjual nasi beserta lauk pauk, dengan harga ekonomis sesuai dengan kantong karyawan. Dan waktu perasionalnya adalah pada jam 07.00 - 20.30 WIB.

Bauran pemasaran yang ada pada warung nasi Bapak Hj. Rais antara lain (1) Tempat (Place), yang bertempat di jalan Paralon Raya Kecamatan Cigondewah kaler Kota Bandung . (2) Produk (Product), yaitu nasi dengan berbagai macam lauk maupun sayur. (3) Promosi (Promotion), dengan jenis promosi mulut ke mulut (mouth to mouth). (4) Harga (Price), dengan kisaran harganya mulai dari Rp 8.000 hingga Rp 15.000.

Peluang yang ada di warung nasi Bapak. $\mathrm{Hj}$. Rais adalah menu makanan yang banyak dicari dan sering dijadikan menu utama pilihan bagi para mahasiswa yang lapar dan malas memasak. Sedangkan ancaman warung Nasi Bapak. Hj. Rais adalah banyaknya pesaing yang menjual jenis produk yang sama namun dengan fasilitas yang lebih nyaman. Kekuatan pada warung nasi Bapak. Hj. Rais yaitu kemampuan handal Pak Rais dalam memasak dan menyajikan aneka jenis menu makanan yang dijualnya. Sedangkan kelemahan pada warung nasi Bapak. Hj. Rais yaitu kurangnya fasilitas penunjang yang disediakan seperti TV, wifi, dan sebagainya.

Dalam aspek pemasaran, warung nasi Bapak. Hj. Rais hanya memasang spanduk atau papan nama di tempat usahanya. Sedangkan dalam aspek produksi, warung nasi Bapak. Hj. Rais melakukan produksi berbagai menu makanan setiap harinya sekitar 80 piring. Untuk aspek permodalan Pak Rais memulai usaha warung nasi Bapak. Hj. Rais dengan modal awal Rp. 1.500.000. Dan untuk aspek sumber daya manusia warung nasi Bapak. Hj. Rais tidak melakukan perekrutan pegawai, dengan kata lain, Pak Rais hanya dibantu oleh istrinya saja.

Strategi bersaing yang diterapkan warung Nasi Bapak Hj. Rais adalah Pertama, warung nasi Bapak $\mathrm{Hj}$. Rais selalu berfokus pada produk utamanya saja, yaitu nasi campur telor dengan tujuan meningkatkan pelayanan kepada pelanggan untuk mencapai kepuasan pelanggan. Kedua, warung nasi Bapak. Hj. Rais menekan harga jual produk yang dipasarkan dengan tidak mengurangi kualitas bahan-bahan yang dibeli untuk menjual menu makanannya, hal tersebut dapat dilakukan karena Pak Rais memiliki hubungan yang baik dengan para suppliernya.

\section{B. Saran}

1) Bagi pembaca, dengan observasi ini pembaca diharapkan mampu menciptakan suatu bisnis dan menjalankannya dengan strategi yang baik dengan berpedoman pada laporan observasi ini. 
2) Bagi pihak observasi selanjutnya, dengan banyaknya kekurangan yang ada di observasi ini, pihak observasi selanjutkanya diharapkan bisa jauh lebih baik dan mampu memberikan hasil yang dapat menjadi pedoman bagi pembaca dalam berwirausaha.

3) Bagi pedagang, para pedagang lainnya harus mampu mencari strategi yang tepat sesuai dengan kondisi lingkungan dan karakteristik konsumen dalam memasarkan produknya, sehingga bisa bersaing pada persaingan pasar yang sehat.

\section{Jawaban :}

a). Merujuk pada diagram Product Life Cycle, menurut Anda berada pada tahap mana bisnis tersebut? Jelaskan Alasan Anda!

Bisnis pada usaha tersebut di atas berada pada tahap maturity (kedewasaan) di karenakan usaha tersebut sudah berjalan lama lebih dari 10 tahun tepatnya selama 14 tahun.

b). Sebutkan strategi apa saja yang perlu dilakukan agar bisnis tersebut berada pada tahap maturity (kedewasaan) yang relatif panjang?

Startegi Pemasaran Tahap Kedewasaan

Strategi pemasaran yang di tempuh dalam tiga tahap kedewasaan ini dapat digolongkan menjadi tiga macam strategi yaitu :

a. Modifikasi Pasar

Disini perusahaan berusaha menemukan pembeli-peembeli baru bagi produknya.

Beberapa kemungkinan yang dapat dilakukan adalah :

1. Mencari pembeli baru dan segmen pasar baru yang belum pernah mencoba produknya. Misalnya :nilon yang dulunya hanya dipakai untuk parasite, sekarang di gunakan untuk pakaian.

“Untuk Kasus bisnis usaha warung nasi Bapak Hj. Rais upaya mencari pembeli baru dapat di lakukan dengan cara bekerja sama dengan HRD untuk menjadi catering yang 
mensuppy makan karyawan pabriknya, atau misalnya dengan metode kerjasama dengan pemilik kantin di sekolah-sekolah, di rumah sakit, di kampus tidak hanya untuk catering karyawan".

"Dan untuk upaya pencarian segmen pasar baru dapat di lakukan dengan cara memodifikasi produk yang di jual bukan hanya andalan nasi telor originalnya saja tetapi dapat dengan melakukan inovasi produk dengan nasi telor rasa-rasa, missal rasa barbeque, rasa salted egg, rasa balado dan rasa Keju”

2. Manaikkan penggunaan di antara para pelanggan, "Untuk Kasus bisnis warung nasi Bapak Hj. Rais upaya menaikan penggunaan dapat dilakukan dengan cara mempromosiikan kepada pembeli tentang kualitas makanan yang di jual aman di konsumsi untuk semua pembeli dan bisa menjadi menu andalan yang menyehatkan bagi para pembeli.

3. Memperbaiki kembali posisi mereknya untuk mencapai penjualan yang lebih besar, meskipun hal ini tidak mempengaruhi penjualan industry secara keseluruh. "Untuk Kasus bisnis warung nasi Bapak Hj. Rais upaya menaikan penggunaan dapat dilakukan dengan cara mempromosiikan kepada pembeli tentang kualitas bahan baku yang di gunakan higienis sehingga menghasilkan menu makanan yang di jual aman di konsumsi untuk semua kalangan bukan hanya sebagai menu makan karyawan tetapi dapat di konsumsi oleh siapa saja dari anak-anak sampai dewasa di semua gender baik untuk laki-laki maupun perempuan, tanpa harus repor-repot memasak di rumah"

\section{b. Modifikasi Produk}

Modifikasi produk dilakukan dengan cara mengubah sifat-sifat produk yang dapat menarik para pembeli baru. Disamping itu, diharapkan pula pembei lama akan menambah pembeliannya. Beberapa strategi yang termasuk dalam modifikasi produk ini adalah sebagai berikut :

1. Perbaikan kualitas

Strategi perbaikan kualitas ini dapat membantu dalam meningkatkan fungsi produk tersebut, seperti : keawetan, kecepatan, dan kelezatan. Strategi ini akan efektif apabila : 
a. Produk tersebut memang dapat ditingkatkan kualitasnya.

b. Pembeli percaya terhadap perbaikan kualitas tersebut.

c. Banyak pembeli yang tertarik pada kualitas yang sudah ditingkatkan.

"Dalam kasus bisnis warung nasi Bapak Hj. Rais, perbaikan kualitas dapat dilakukan dengan cara penggunaan bahan baku yang berkualitas, misalnya penggunaan beras, minyak goring, dan bumbu-bumbu yang berkualitas.

2. Perbaikan fitur

Dalam perbaikan fitur (feature improvement) ini perusahaan dapat menambah fitur baru yang dapat meningkatkan keamanan atau perlindungan dan keparaktisan suatu produk. "Dalam kasus bisnis warung nasi Bapak $\mathbf{H j}$. Rais, perbaikan fitur dapat dilakukan dengan cara penggunaan fasilitas-fasilitas pendukung untuk kenyamanan pembeli, misalnya penggunaan wifi, penyediaan sarana tempat beribadah, sarana khusus makan anak-anak dll”.

3. Perbaikan corak (style)

Dalam perbaikan corak (style) ini, perusahaan melakukan upaya-upaya yang lebih mengutamakan pada keindahan dari pada yang lain. Untuk barang-barang seperti makanan dan barang konsumsi lainnya, kemasan dapat mencerminkan sebagai corak. Dapat terjadi bahwa sebagai sebagian pelanggan justru lebih menyukai corak yang lama. Jika corak lama tersebut ditinggal , maka perusahaan dapat kehilangan sebagian pelanggannya.

"Dalam kasus bisnis bisnis warung nasi Bapak Hj. Rais, perbaikan Corak dapat dilakukan dengan cara penggunaan identitas pedagang berupa sticker identitas pedagang lengkap dengan alamat dan nomor telepon yang dapat di hubungi untuk pemesanan, sticker dapat di tempel pada kemasan tray makanan yang di take away”

\section{c. Modifikasi bauran pemasaran}

Strategi terakhir yang dapat dilakukan untuk produk yang sudah mengalami tahap kedewasaan adalah modifikasi bauran pemasaran. Manajer mempertimbangkan untuk mengubah elemenelemen bauran pemasaran untuk mendorong penjualannya. Beberapa alternatife yang dapat di tempuh adalah sebagai berikut :

a. Menurunkan harga untuk menarik segment-segment baru. 
b. Mengadakan periklanan yan glebih menarik atau promosi lain yang lebih agresif.

c. Megalhkan jalur distribusinya ke saluran distribusi yang lebih menguntungkan atau yang menghasilkan volume penjualan lebih besar.

"Dalam kasus bisnis warung nasi Bapak Hj. Rais, modifikasi bauran pemasaran dapat dilakukan dengan cara :

a. Memberikan paket hemat pembelian, misalkan pembelian 10 piring berhadiah satu piring untuk pemesanan maksimal.

b. Mempromosikan adanya warung nasi tersebut pada group watssupp pemilik, dan semua pihak/keluarga yang mengetahui keberadaan warung nasi tersebut. Selain dengan acara promosi dari mulut kemulut.

c. Mengalihkan distribusi penjualan dengan cara menjadi catering penyedia menu makanan bagi para pembeli dengan minimum quantity pembelian dan pemberian harga khusus / discount bagi yang mempromosikan.

c). Sejauh mana bisnis tersebut dalam memanfaatkan digital marketing (social media, web, dan sejenisnya)

Bisnis tersebut belum memanfaatkan digital marketing (social media, web, IG dll) yang maksimal atau dengan cara bekerjasama menjadi rekanan jasa model transportasi yang sudah kekinian seperti mejadi rekanan Gojeg untuk fitur Gofood, belum beriklan di instagram, dan group social media watssupp dan promosi pada social media lainnya, terlebihlagi untuk promosi pada media social yang lebih luas seperti iklan radio ataupun mempunyai website sendiri.

\section{Referensi}

Hidayat, L., Mulyana, M. and Effendy, M., 2018. Membangun Kepuasan Mahasiswa Pengguna Laboratorium Komputer. JAS-PT Jurnal Analisis Sistem Pendidikan Tinggi, 1(2), pp.93101.

Mulyana, M. and Khrisnayoga, P.P., 2019. OBSERVASI PERILAKU KONSUMEN DALAM BERBELANJA ONLINE.

Pauziah, P. and Mulyana, M., 2018. Formulation of The Green Marketing Development Strategy for the Body Shop Botani Square Bogor. In THE INTERNATIONAL CONFERENCE ON ACCOUNTING AND MANAGEMENT SCIENCE (p. 171).

Pasaribu, K., Anggraeni, Y. and Fadillah, A., 2010. PENGARUH ATRIBUT PELAYANAN TERHADAP KEPUASAN KONSUMEN (Studi Kasus pada PT Kuala Sarana SejahteraPuri Begawan). Jurnal Ilmiah Ranggagading, 10(2), pp.165-172. 
Jaya, P.I.N.T.O., Fadillah, A.D.I.L. and Bawono, S., 2012. ANALISIS STRATEGI USAHA RITEL UKM DALAM MENINGKATKAN KEUNGGULAN BERSAING STUDI KASUS PADA UKM TOKO MOJANG FASHION. In 2012 Marketing Symposium, 1 (1).

Retna, D.W. and Sulistiono, A., 2014. PENGARUH KUALITAS PRODUK DAN KUALITAS PELAYANAN TERHADAP KEPUASAN PELANGGAN. Jurnal Ilmiah Manajemen Kesatuan, 2(3).

Binangkitsari, L. and Sulistiono, S., 2018. The Influence of Brand Equity Elements on Purchase Decision and Its Imlication on Customer Loyalty. In THE INTERNATIONAL CONFERENCE ON ACCOUNTING AND MANAGEMENT SCIENCE (p. 305). 